\title{
Theorizing state-diaspora relations in the Middle East: Authoritarian emigration states in comparative perspective
}

\author{
Gerasimos Tsourapas \\ Department of Political Science \& International Studies, University of Birmingham, \\ Birmingham, UK
}

\begin{abstract}
Recent scholarly interest in the politics of migration and diaspora across the Global South has yet to address how authoritarian states attempt to reach out to populations abroad. In an effort to shift the discussion on state-diaspora relations beyond liberal democratic contexts and single-case studies, this article comparatively examines how authoritarian emigration states in the Middle East - Libya, Syria, Egypt, Turkey, and Jordan - behave towards their own citizens living beyond state borders. It identifies how each state develops multi-tier diaspora engagement policies aimed at three separate stages of citizens' mobility: first, policies of exit regulate aspects related to emigration from the country of origin; second, overseas policies target citizens beyond the territorial boundaries of the nation state; finally, return policies set processes of readmission into the country of origin. In doing so, the article identifies similarities across disparate Middle East states' engagement with emigration and diaspora policymaking. At the same time, the article paints a more complex picture of non-democracies' strategies towards cross-border mobility that problematizes existing conceptualizations of authoritarian practices and state-diaspora relations.
\end{abstract}

\section{Introduction}

On 19 November 2016, Azza Soliman, the Egyptian founder of the Centre for Egyptian Women's Legal Assistance, made her way to Cairo International Airport. She was planning to take a flight to Jordan to participate in a workshop on human rights, but it was not meant to be; Soliman was informed by authorities that she had been banned from travelling outside Egypt, together with hundreds of Egyptian citizens (Michaelson, 2016). A few months earlier, in a similar attempt at a clampdown on political dissent in Turkey, the Erdoğan government banned thousands of academics from travelling abroad (The Independent, 2016). At the same time, both the 
Egyptian and Turkish regimes have been funnelling considerable resources towards citizens who have already moved abroad - most recently, in the efforts to court their diasporas' vote for the March 2018 Egyptian presidential elections and the April 2017 Turkish referendum, respectively. In warravaged Syria, the Assad regime introduced Law No. 10 to allow the seizure of private property, in an effort to discourage Syrians abroad from returning to the homeland (Associated Press, 2018). While states across the Middle East develop complex strategies aimed at managing cross-border population mobility, the relevant literature has yet to sufficiently theorize this phenomenon in a comparative manner. How do authoritarian states aim to manage their citizens' cross-border mobility?

States' policies towards emigration and diasporas have diffused into a global phenomenon (for recent overviews, see: Délano Alonso \& Mylonas, 2017; Koinova \& Tsourapas, 2018), with the majority of states developing a range of diverse policies that go beyond mere consular support for expatriates. A growing number of states are implementing out-of-country voting processes (Lafleur, 2013), dual citizenship provisions (Mirilovic, 2014), as well as a variety of policies that aim to strengthen connections to the homeland (Gamlen, 2014). A sizeable body of literature has built on archetypical cases of liberal democracies' development of migration and diaspora institutions namely India (Naujoks, 2013), Mexico (Fitzgerald, 2009), and the Philippines (Rodriguez, 2010). Building on this work, social scientists are now identifying how non-democracies also target citizens residing outside the boundaries of the nation state. ${ }^{1}$ An emerging literature identifies the development of diaspora engagement policies in Syria (Moss, 2018), Morocco (Dalmasso, 2018), Eritrea (Hirt \& Mohammad, 2017), Egypt (Brinkerhoff, 2005; Tsourapas, 2018a), Tunisia (Natter, 2015), and elsewhere. Even though research acknowledges that regime type matters in states' diaspora policymaking (Glasius, 2017; Koinova \& Tsourapas, 2018; Mirilovic, 2016), scholars have yet to examine the linkages between authoritarian emigration states' diaspora policies and repressive policies within the borders of the nation state. $^{2}$ Do authoritarian states develop identical sets of diaspora engagement policies with liberal democracies and, if not, do they face additional constraints or opportunities? Ultimately, what is the range of policies developed by authoritarian emigration states?

To address these questions and stimulate further comparative research on state-diaspora relations in the Global South, I examine the various ways through which how states in the Middle East attempt to engage with their population groups abroad. In contrast to the expectations of the literature for homogenous diaspora policies, ${ }^{3}$ | build on earlier research to argue that authoritarian emigration states develop "multitier" diaspora policies (Tsourapas, 2015b; cf. Han, 2017). They engage with different sets of emigrants in three separate stages of their mobility: 
first, policies of exit regulate aspects related to emigration from the country of origin; second, overseas policies target population groups beyond the territorial boundaries of the nation state; finally, return policies set processes of readmission into the country of origin. While I do not expect to create a comprehensive typology of the range of authoritarian emigration states' diaspora policies, I aim to problematize existing conceptualizations of frequently unitary diaspora policymaking based upon liberal democracies, while also moving away from single case study analyses that tend to dominate the field.

The article proceeds as follows: I begin by examining the literature on states' diaspora policies more closely, and I identify a gap in the diverse manners through which authoritarian emigration states attempt to reach out to their populations abroad. I continue by arguing for a multi-tier approach to diaspora policymaking in non-democratic contexts, before proceeding to examine the policies of five Middle Eastern states - Libya, Syria, Egypt, Turkey, and Jordan - in the pre-2011 period. The case selection aims to maximize variance in degree of authoritarianism, ranging from the Libyan and Syrian dictatorships to Jordan's parliamentary monarchy and the hybrid regimes of Egypt and Turkey. I identify how each state developed multi-tiered emigrant policies, targeting different population groups at different stages of mobility. ${ }^{4}$ I draw on primary sources (World Bank data, NGO reports, and Arabic media sources) as well as secondary literature. I conclude with a discussion of how the article's theorization and argumentation may be carried forward in the future.

\section{Diaspora policymaking in authoritarian emigration states}

This section examines how scholars have approached the question of nondemocracies' policymaking towards their citizens abroad to highlight a lack of engagement with the full range of policies developed by such states. Social scientists have traditionally approached authoritarian states as aiming to restrict their citizens' cross-border mobility and prevent emigration at any cost (Alemán \& Woods, 2014; Hirschman, 1993, p. 179). This was a Cold War perspective shaped by the construction of the Berlin Wall and the German Democratic Republic's shoot-to-kill policy towards anyone aiming to cross it. With the 'transnational turn' in international relations over the last 20 years, scholars shifted their attention to diaspora policies, gradually beginning to theorize as to the conditions under which liberal democratic 'emigration states' reached out to their communities abroad (Collyer, 2013; Gamlen, 2008). This strand left a gap with regard to authoritarian states' strategies (for exceptions, see: Brand, 2006; Shain, 2005; Østergaard-Nielsen, 2003). A recent wave of scholarship has addressed this by examining both how diasporas interact with 
authoritarian politics at home (Betts \& Jones, 2016; Escriba-Folch, Meseguer, \& Wright, 2018) as well as how autocratic governments develop policies to govern their populations abroad (including a special issue of Globalizations, edited by Glasius, 2017).

I argue for the need to examine the workings of 'authoritarian emigration states', namely 'the set of institutions, practices, and mechanisms regulating cross-border mobility developed within non-democratic contexts' (Tsourapas, 2018a, p. 403). In doing so, I highlight how a liberal democratic framework of diaspora policymaking faces an important hurdle when applied to this subset of states: authoritarian emigration states aim to exert, by definition, a greater degree of control throughout citizens' migration trajectory. For one, permission to leave or return to one's country of origin, which liberal democracies recognize as individual right, ${ }^{5}$ is subject to the political exigencies of authoritarian emigration states. To understand non-democracies' diaspora outreach, it is necessary to problematize who is allowed to become diasporic. For citizens aiming to emigrate from Uzbekistan or North Korea, for example, exit visas continue to remain a strict requirement; Cuba only abolished the practice in 2013. Particularly in previous decades, 'black lists' were a prominent phenomenon that contained citizens that were specifically prohibited from emigrating, as in the case of the Soviet Union and the Warsaw Pact states.

At the same time, the long arm of authoritarian emigration states also reaches out to citizens who have emigrated. Citizens abroad may find themselves being monitored by embassy and consular staff or groups affiliated with them - as in the case of the Tunisian and Moroccan amicales that operated across Western Europe (Brand, 2002). As will be seen below, authoritarian emigration states have not hesitated to target citizens' family and friends in the homeland as retribution for citizens' political activism abroad. Many states are able to support authoritarianism via financial extraction from diaspora communities - as in the case of Eritrea. In even more extreme cases, a number of authoritarian emigration states have also not hesitated to diminish 'opposition in exile' through forced extraditions, as in Central Asia or, even, to engage in political assassinations, as in the case of Russia under Putin (Tsourapas, 2018b).

Finally, authoritarian emigration states regulate citizens' return migration processes. They may not allow dual citizenship or may engage in denaturalization of dissenters. This is particularly popular across the Gulf states (The Economist, 2016). Qatar revoked the citizenship of an entire clan, approximately 6,000 members of the Al-Ghufran branch of the Al-Murrah tribe in the 2004-2005 period, because of lack of loyalty to the Emir (Parolin, 2009). In June 2017, Vietnam denationalized political dissident Pham Minh Hoang, a member of the Vietnam Reform Party that the government considers a 'terrorist group', preventing his return to the homeland (Al-Jazeera, 2017). In 
less extreme cases, passports may be confiscated, or not renewed - either as a way of severing one's ties to the homeland or forcing their return.

Overall, beyond policies that exclusively target those citizens already residing outside its borders, non-democracies develop two additional sets of policies aiming to control emigration and return migration. Authoritarian emigration states arguably develop multi-tier diaspora policies targeting three separate stages of cross-border mobility: exit, overseas, and return (see Table 1). While some overlap exists between these tiers, as will be analysed below, this conceptualization demonstrates how states view diaspora communities as dynamic and attempt to affect them via diverse sets of policies. As seen above, most states today develop policies aiming to engage with populations abroad; in non-democratic contexts, these policies also control these populations' expansion or decline. States, in Adamson's apt characterization, are able to both 'generate' and 'shape' diasporas (Adamson 2018); arguably, authoritarian emigration states may also seek to 'dismantle' them.

\section{Theorizing diaspora policymaking in the Middle East}

This section employs the exit, overseas, and return analytical framework of diaspora policymaking outline above in the context of the Middle East. It examines how five authoritarian emigration states - Libya, Syria, Egypt, Turkey, and Jordan - have engaged with population groups abroad, and demonstrates key commonalities and differences among them.

Table 1. Typology of multi-tier diaspora policies in authoritarian emigration states.

\begin{tabular}{ll}
\hline $\begin{array}{l}\text { Diaspora } \\
\text { Policy-Tier }\end{array}$ & \multicolumn{1}{c}{ Policy Examples } \\
\hline Exit & Legal regulations regarding the issuance of travel documents \\
& 'Black lists' preventing select individuals' cross-border mobility \\
Informal processes hindering emigration & Restrictions on travel based on age, sex, occupation, fulfilment of military service \\
obligations, political activity, or criminal records \\
Bilateral agreements with (potential) host states \\
Intimidation, corporal punishment, or assassination of citizens residing abroad \\
Financial extraction, through taxation or other means \\
Organisation of informant networks gathering information and reporting on \\
citizens' activities \\
Forced participation in regime-sponsored activities or celebrations \\
Targeting of citizens' family and friends in the homeland as retribution \\
Diplomatic pressure on host states for cooperation \\
Limited out-of-country voting provisions \\
Dual/multiple citizenship not allowed or tightly-regulated \\
Cancelling as well as refusing to issue or to renew passports and other travel \\
documents to individuals abroad \\
Practices of denationalisation \\
Forced extradition processes \\
Development of 'black lists' banishing individuals' return, including via threat of \\
harm
\end{tabular}




\section{Libyan diaspora policies}

Oil-rich Libya is traditionally examined as a country of immigration or, more recently, transit migration (Bredeloup \& Pliez, 2011; Paoletti, 2010). While outflows never reached the high figures of other Middle Eastern and African states, Libya experienced sustained emigration, particularly temporary emigration of students and high-skilled professionals, dispersed across multiple host states (Figure 1). Short-term emigration can be explained primarily from a developmental perspective: Idris, the first ruler of post-independence Libya (1951-1969), relied on foreign staff to develop the Libyan state and train Libyan citizens (Tsourapas, 2015a; Vandewalle, 2012), but his successor, Muammar Gaddafi, encouraged the emigration of Libyans for skill-acquisition purposes, instead. Political scientists have examined how Libyan elites have manipulated the status of the country both as a transit and as a host country of migrants for economic and foreign policy gains in its migration diplomacy (Tsourapas, 2017; Paoletti, 2011; cf. Greenhill, 2010); yet, little has been written on the country's complex diaspora policy.

With regard to managing emigration through the state's exit policy, postindependence Libya initially regulated emigration almost at the point of restriction. The ruling regime considered a Libyan's relocation abroad to constitute a political act hostile to the state, and duly developed a variety of repressive mechanisms: it instituted a rigid system of exit-visa regulations for Libyan nationals. The issuance of travel documents was also extremely complex, having to go through a number of bureaucratic and administrative channels. This process was bound to be unsuccessful, or result in imprisonment, if one had been placed on one of the regime's 'black lists', merely by being a relative of another Libyan abroad. A gradual shift occurred in the years following Gaddafi's 1969 Revolution.

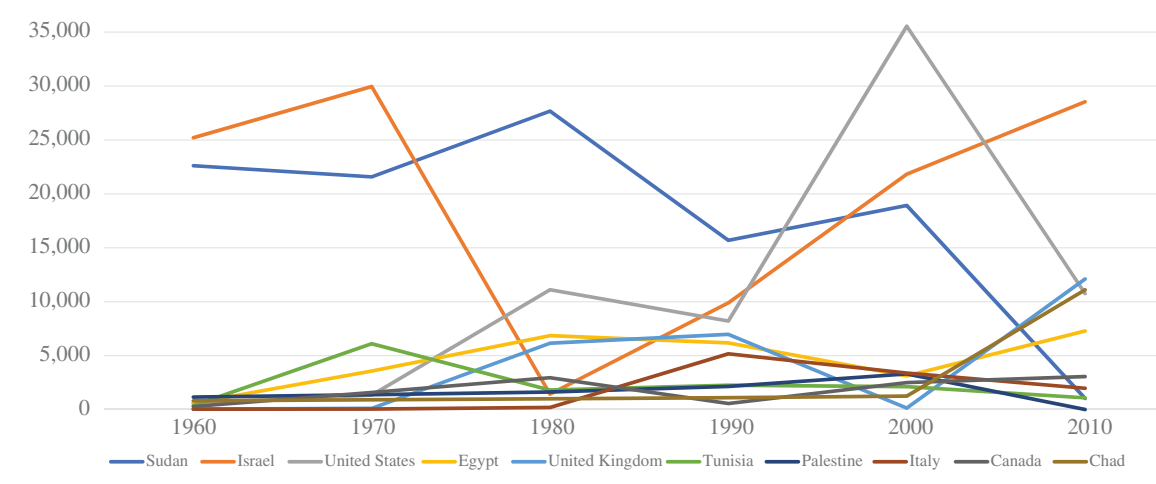

Figure 1. Libyan migrant stock in major countries of destination [1960-2010]. Source: World Bank (2011) 
Eager to rid Libya of its dependence on foreign labour and conduct a 'Libyanization' of the country's workforce (Maghur, 2010, p. 3), Gaddafi gradually encouraged the emigration of Libyans for skill-acquisition purposes and expanded a programme for scholarships to study abroad. The requirement of 'exit visas' was formally dropped in 1991, although female Libyan citizens continued to not be able to travel abroad without written authorization from their father or husband (Obeidi, 1999, p. 171). Although research on Libyan emigration is scant, there is ample evidence of 'arbitrary seizure or non-issuance of passports' (United States Department of State, 2012). In the 2004 case of Loubna El Ghar v. Socialist People's Libyan Arab Jamahiriya, the United Nations Human Rights Council determined that Libya refused the issuance of a passport 'without any valid justification and ... prevented [her] from travelling abroad to continue her studies' (Harvey \& Barnidge, 2005, p. 5). The state also imposed heavy penalties on those who attempted to emigrate without proper permission, while the facilitation of unauthorized emigration carried both a prison penalty and a fine, as formalized in Law No. 2 |2004 and Law No. 19 |2010.

The Libyan state under Gaddafi also developed an extensive overseas diaspora policy that aimed to exert control over the activities of citizens that had permanently relocated abroad. In the UK, this included efforts in mobilizing Libyan students against potential anti-regime activists, organized by Omar Sodani in the early 1980s (for an account of the era, see: Kawczynski, 2011, pp. 88-111). The Gaddafi regime would describe many of those who had fled abroad as traitors to the Libyan state or, more frequently, kullāb dâla ('stray dogs'), and would threaten vengeance. In his 1982 'Day of Vengeance' speech, ${ }^{6}$ Gaddafi included these political dissenters to the same group as the Libyan Jews that had been ousted earlier: 'these stray dogs composed of ex-premiers who are traitors and hirelings...' Gaddafi stated. 'They demean the Libyan people because they sold out Libya ... There shall be no mercy for the agents of America. The escaped hirelings, enemies of the Libyan people, shall not escape from this people' (quoted in Ross, 1982). In the Libyan case, patriotism and loyalty to the regime entailed a rejection of the West (cf. Shain, 2005), which rendered emigration politically suspect.

Teams of rough and ready revolutionaries moved in and took over the Libyan embassies (now named 'people's bureaus') around the world and began rooting out the 'stray dogs' who were engaged in anti-regime activities. Eliminating the opposition was far more important to Qaddafi than the niceties of foreign diplomacy (Pargeter, 2012, pp. 103-104).

Libyan strategies of silencing the diaspora included political assassinations (Ross, 1982). These campaigns were reportedly organized by Moussa Koussa, nicknamed mab'üth al-mawt ('envoy of death'), for he also organized covert assassination attempts against Libyan opposition figures abroad. In 1980, 
Koussa was formally removed from his position as public envoy in London when he publicly admitted these practices to the London Times: 'We killed two in London and there were another two to be killed ... I approve of this' (The Times, 11 June 1980). Earlier that month,

'On 11 April 1980, Mohamed Ramadan, a Libyan journalist with the BBC's Arabic Service, who had been publishing open letters to Qaddafi in the Arabic media, was shot at point-blank range in the courtyard of the Regent's Park mosque after Friday prayers. The Libyan authorities refused to accept his body back for burial. Ramadan's death was not a one-off: the same month Libyan lawyer Mahmoud Abu Nafa was shot dead in the offices of a legal firm in Ennismore Gardens in London, a street that at the time also housed the education offices of the Libyan People's Bureau ... In May 1980, a wealth Libyan timber merchant was murdered in his hotel bed in Rome. The following month Izzadine Al-Hodeiri, a Libyan living in Bolzano in northern Italy, was shot dead in the railway station in Milan. At the same time, a naturalised Italian of Libyan birth, Salem Fezzani, was shot at in the Rome restaurant he owned. The attacker told the police: 'I was sent by the people to kill him. He is a traitor and an enemy of the people' (Pargeter, 2012, pp. 104-105).

Many dissidents mysteriously disappeared, such as former Minister of Foreign Affairs (1972-73) Mansour Rashid El-Kikhia. Having disagreed with Gaddafi's policies, El-Kikhia was granted an American citizenship and went on to help found the Arab Organization of Human Rights. He disappeared in Cairo in 1993, and his remains were only discovered in Libya in 2012. As Salem al-Hassi, Libya's Intelligence Chief following the 2011 ousting of Gaddafi (2012-15) recounts:

'I was not the only one who was pursued by the Gaddafi intelligence services. For years, the Gaddafi intelligence services went after opposition leaders in the capitals of many countries, in Europe, the United States and Arab countries. A great number of opposition leaders were handed over Gaddafi by Arab and European countries. A great number were kidnapped in Arab and European countries. The regime used the most evil ways to eliminate the opposition' (quoted in Asharq al-Awsat 2012).

Finally, beyond aiming to control diasporic activity by targeting Libyans who wished to exit and those abroad, the Gaddafi regime also tailored its return diaspora policy along similar aims. The regime would attempt to have Libyan dissenters returned to the homeland to face persecution and appropriate punishment. The intended aim was to dissuade Libyans from emigrating by highlighting the risks involved. Not surprisingly, the regime's treatment of return migrants often involved public show trials. One of the most chilling was the case of Al-Sadek Hamed al-Shuwehdy, who had emigrated to pursue an engineering degree in the United States. He was publicly executed in 1984, in the middle of a stadium full of thousands of school children and students, who had been brought in for the occasion. After he tearfully confessed that he 
has joined the 'stray dogs', a gallows was brought into the arena and alShuwedhy was hanged on live state television (Black, 2011).

Such violence was also aimed at dissuading any Libyan exiles from returning to the homeland as well as disciplining those already abroad demonstrating how different tiers of Libya's diaspora policy may overlap. At the same time, the state's diaspora policy also developed a rigid legal framework for restricting any attempts at repatriation: for one, dual citizenship was expressed forbidden as per Nationality Law No. 17|1954, and Law No. 3 |1979. A common measure adopted for political dissenters abroad, or those who had emigrated without formal permission, was denaturalization: for instance, Ali Tarhouni, a key figure in post-2011 Libyan politics, had fled the country in 1973, was stripped of his citizenship, sentenced to death in absentia, and placed on a government hit list in 1981 (Fahim, 2011). The Libyan state had introduced detailed regulations on how the process of involuntary loss of Libyan citizenship occurs, on the following grounds:

'Person obtains new citizenship without government permission. Person enlists in foreign military or attempts to avoid Libyan conscription. Person seeks asylum in another country. Person attempts to smuggle money out of the country. Person converts to a religion other than Islam. Person deserted country after 1969 revolution. Person refuses to return home within 6 months of state request. Person commits treasonous acts against the state. Additional grounds for a naturalized citizen: Person commits crimes against the security of the state. Person remains outside the country more than two years. Person obtained citizenship through fraud or false statement' (Libyan Arab Jamahiriya, 1979).

\section{Syrian diaspora policies}

Similar to Libya, the Syrian Arab Republic, or Syria, is another Middle Eastern country that is not traditionally considered as an emigration state given the numerous restrictions that the Assad regime placed on population mobility (Philipp, 1985; Winckler, 1997). Yet, Syria has experienced waves of lowskilled emigration into Lebanon for decades (Chalcraft, 2008), Venezuela, as well as into the Gulf countries from the mid-1970s onwards (Figure 2). Similar to the Libyan case, Syrians also fled the political regime of Hafez al-Asad by emigrating to the West, particularly during the 1980s which saw a wave of harsh repression.

In terms of Syria's exit policy, Syrians were able to pursue short-term labour emigration into Lebanon and the Gulf Cooperation Council states; this was supervised by the regime via bilateral accords with the Arab host states and is best understood as a socio-economic 'safety valve': unemployed, low-skilled Syrians had the opportunity to pursue temporary or cyclical employment in Lebanon; medium- or high-skilled Syrians sought employment in the oilproducing Arab countries of the Gulf instead. The state regulated this process 


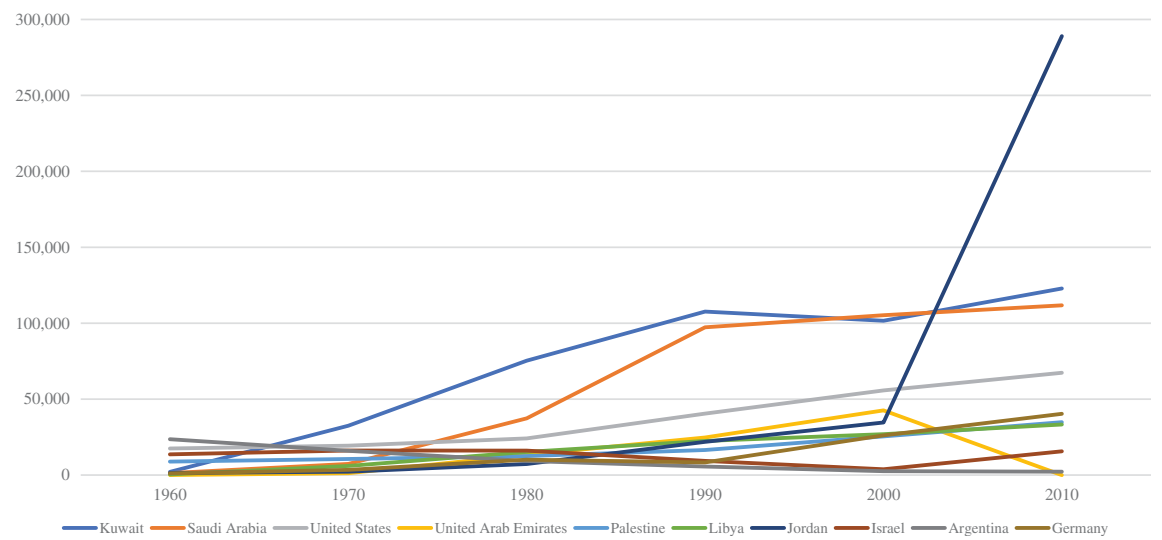

Figure 2. Syrian migrant stock in major countries of destination [1960-2010]. Note that Syrians' large-scale circular migration into Lebanon is not captured in World Bank data.

Source: World Bank (2011).

by requiring two documents from a prospective emigrant: one would state that the individual was either unemployed (or employed in the private sector) or, in the case of public sector workers, that he/she had permission from the government to leave the country. A second document would state successful completion of military service, or exemption from it. Border control officials also possessed lists of Syrian citizens barred from travel abroad. This effectively prevented regime dissenters or political activists from leaving the country. At the same time, the regime was also keen to 'preventing the migration of skilled and professional workers by means of coercion and by denying exit visas to those who were important to the economy' (Winckler, 1997, p. 113). This was notably the case with Syrian engineers who, according to a 1988 law, were forbidden from emigrating until they had been employed in the public sector for at least 5 years. This is not to suggest that political dissenters did not manage to leave Syria; however, bilateral agreements with neighbouring countries prevented irregular Syrian emigrants from travelling to a third country (for they either did not have travel documents or lacked the Syrian exit stamp on their passport).

Those citizens that settled abroad were subject to Syria's overseas policy. With regard to any unauthorized political activism abroad, the Syrian state would target the emigrant's family members back home, not unlike Libyan strategies: in case a Syrian abroad engages in unauthorized political activism, his/her family members in Syria would be forbidden from emigration, and authorities would launch an investigation on their activities. A notable example is Mohamad Mamoun Alhomsi, an independent member of the 
Syrian parliament, and a signee of the 2005 Damascus Declaration, who fled to Lebanon in 2006 after serving a prison sentence for 'attempting to change the constitution by illegal means'. State security forces detained his 16-year-old son Yasin overnight 'hoping to lure his father back'. A few years later, Yasin was placed in prison and, when released 7 months later, he was forbidden from leaving Syria (Carman, 2015). Beyond blurring the line between 'exit' and 'overseas' policies, the targeting of one's family members back home casts into doubt whether it is possible to ever fully escape the grip of the authoritarian emigration state.

Syria also followed Libya's example of monitoring diaspora communities and exerting violence on dissenters abroad. Reports of Syrians' disappearances abroad have gone unanswered. Assassinations have not been uncommon: Muhammad Umran, a founding member of the Ba'ath Party, was imprisoned following the 1966 Syrian coup d'état; he fled to Lebanon upon his release, where he was assassinated in March 1972. Salah ad-Din al-Bitar, another founder of the Ba'ath Party and later Prime-Minister of Syria, fled to Europe in 1966. He was shot in the back of the neck in July 1980 in Paris, after calling for the overthrow of Asad. Two weeks beforehand, Syrian radio had declared that 'Syria is capable of firmly striking at all the hands attempting to harm it', while the al-Ba'ath paper warned that 'the hand that is directed against Syria will be cut off be it directed from abroad or internally' (Koven, 1980). In March 1981, Banan al-Tantawi was assassinated inside her home in Aachen, Germany (Reuters, 1981). She was the wife of exiled Syrian Muslim Brotherhood leader Isaam el-Attar, who had been prohibited from returning to Syria from Saudi Arabia in 1964 (and who was reported to have been the target for assassination). As with the Libyan authoritarian emigration state's practices, it bears noting that only prominent figures targeted abroad are known to the wider public; the full list of those citizens targeted by Syria's overseas policy is likely to be much longer.

Finally, in terms of return policy, the Syrian regime developed strategies reminiscent of Libya. Dual nationality required authorization from the Syrian authorities, and the state put forth legal sanctions in case of acquisition of a second nationality without authorization. Beyond other criteria, such authorization was expressly subject to the previous fulfilment of military service obligations. Unlike Libya, however, Syria's diaspora policy preferred to have political opposition figures returned to the homeland, rather than denaturalize them while abroad. Syrian dissenters abroad were granted documentation to return, merely to be arrested upon entering Syria: when Medhat Tayfour, for instance, who had left the country in 1983, applied for permission to return to Syria from Jordan, he was given a laissez-passer travel document but was arrested at the border on 1998 and never seen again. His brother was a member of the Muslim Brotherhood in exile (Human Rights Watch, 1999, p. 376). The strictly enforced rule of having to serve a 2-year military service for 
any Syrian abroad that did not do so before emigrating (or pay a hefty waiver fee) is also a major factor prohibiting return.

Cutting across Syria's overseas and return policies is a long-standing culture of fear among Syrians abroad against the workings of state embassies and consulates abroad (Ibid.). It is common knowledge that members of the feared Air Force Intelligence Directorate (Idarat al-Mukhabarat al-Jawiyya) are stationed in every Syrian embassy or consulate, although these officers are more involved in the surveillance of staff than of citizens abroad. Diaspora communities' reports of intimidation and harassment have multiplied since the onset of the Syrian Civil War (Amnesty International, 2011; Moss, 2016). Assessing the validity of these claims - ranging from verbal abuses by staff to the existence of prison cells within embassies' basements - is not important, for they are able to dissuade Syrians abroad from engaging with state officials irrespective of their accuracy. By representing the long arm of the authoritarian emigration state, these Syrian institutions shape state-diaspora relations in a diffuse manner, similar to the North African amicales across Western Europe (Brand, 2002): they are able to affect diaspora groups' conduct abroad effectively without resorting to conspicuous acts of violence.

\section{Egyptian diaspora policies}

While Egyptian migrants worked across the Arab world and Africa for most of the twentieth century (Amin \& Awni, 1986; Awad \& Selim, 2017; Tsourapas, 2016), Egyptian migration increased significantly in the Sadat and Mubarak era (1970-2011), both towards the oil-producing countries of the Arab world (Fergany, 1983), as well as towards the West (Zohry \& Harrell-Bond, 2003). Sizeable Egyptian migrant stocks exist across the Arab world today, particularly in Saudi Arabia (Figure 3), as well across Europe, North America, and Australia.

In contrast to the exit policies developed by Syria and Libya, Egypt under Presidents Anwar Sadat and Hosni Mubarak approached its citizens' emigration as a right (Dessouki, 1982; Author). Article 52 of the 1971 Constitution declared that 'citizens shall now have the right to permanent or temporary migration' (Arab Republic of Egypt 1971). Exit visas, which President Gamal Abdel Nasser used to restrict emigration in the 1950s and 1960s, were abolished in 1974, and the state ceased collecting data on emigration. Furthermore, according to Presidential Decree 73|71, public sector employees who emigrated in pursuit of employment abroad to be reinstated in their positions in Egypt, if they returned home within a year after their resignation (later 2 years), with any salary increments they missed to also be considered. A number of agreements were negotiated with migrant host states (Table 2). Egyptian school curricula were instructed to teach that 'people emigrate, just like the birds' (Al-Ahram al-lqtisadi, No. 745, 1983). The 1977 preparatory school certificate exam asked students to write an 


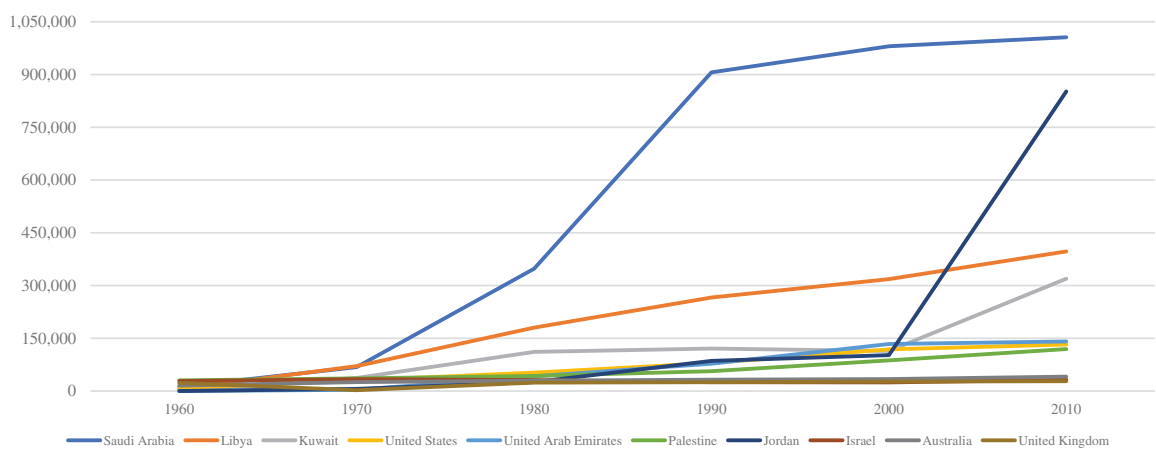

Figure 3. Egyptian migrant stock in major countries of destination [1960-2010]. Source: World Bank (2011)

essay on 'the joys of a person who could obtain work in an Arab country' (alAhram, 18 May 1977).

With regard to its overseas policy, the Egyptian regime would attempt to reach out to these migrant and diaspora communities in a variety of ways following the liberalization of emigration in the early 1970s (Tsourapas, 2015b). Not unlike other developing countries, a major aspect of Egypt's diaspora policy built on the perceived political and economic gains of embracing its diaspora in the West. A large number of them would frequently be invited back to Cairo and Alexandria, where they would be

Table 2. Emigration-related agreements between Egypt and Arab States, 1971-2011 (Treaties, memoranda of understanding and protocols).

\begin{tabular}{ll}
\hline Year & \multicolumn{1}{c}{ Countries } \\
\hline 1971 & Egypt - Libya \\
1972 & Egypt - Algeria \\
1974 & Egypt - Jordan \\
1974 & Egypt - Qatar \\
1975 & Egypt - Iraq \\
1981 & Egypt - Jordan \\
1985 & Egypt - Jordan \\
1985 & Egypt - Iraq \\
1993 & Egypt - Iraq \\
1993 & Egypt - Lebanon \\
1993 & Egypt - United Arab Emirates \\
1994 & Egypt - United Arab Emirates \\
1994 & Egypt - Libya \\
1997 & Egypt - Yemen \\
1998 & Egypt - Lebanon \\
2001 & Egypt - Tunisia \\
2003 & Egypt - Sudan \\
2007 & Egypt - Jordan \\
2007 & Egypt - Saudi Arabia \\
2009 & Egypt - Libya \\
\hline
\end{tabular}

Source: Tsourapas, 2015b 
entertained by the President and the First Lady under both the administrations of both Presidents Sadat (al-Jumhuriya, 4 August 1976) and Mubarak (al-Ahram, 2 August 2010). In the aftermath of the 1973 Arab-Israeli War, about 1500 emigrants from North America would receive annual tours of the Suez war front hosted by various cabinet ministers (al-Ahram, 17 June 1974; al-Jumhuriya, 27 August 1976). Those studying in Europe and North America would receive financial support from the Egyptian President on an ad hoc basis - a grant of $\$ 50,000$, or $\sim \$ 212,000$ today, was given to the Union of Egyptian students in North America, for instance (al-Ahram, 9 August 1976), while any problems were to be dealt with immediately, regardless of cost. At one point, Sadat even had the Presidential airplane transport home Egyptians who had been unable to find employment in France (al-Jumhuriya, 12 July 1975). A number of different committees and other institutions developed that were responsible for emigrants, including a separate Ministry of State for Emigration Affairs (created in 1981), which was replaced in 1996 by the Ministry of Manpower and Emigration.

Scant research exists with regard to the repressive nature of Egypt's diaspora policies. The violence - overt or otherwise - that characterized the Libyan and Syrian states' workings with citizens abroad appears to not be as prominent in the case of pre-'Arab Spring' Egypt. One explanation may be that Egyptian diaspora groups never constituted a sufficient threat to the ruling regime to warrant the development of repressive mechanisms; yet, reports of diasporic anti-regime activism (particularly by the Coptic diaspora) are frequent. A more convincing answer may relate to Egyptian migrants' choice of destination: the vast majority of Egyptians sought employment in Iraq and the Gulf Cooperation Council states, which offered scant opportunities for political activism. At the same time, given the close security cooperation between sending and host states' security sectors (Feiler, 2003) and the absence of democratic norms at work, Egypt relied on its Arab counterparts for monitoring, repression, and control in ways that the Libyan and Syrian regimes could not have replicated in Europe or North America.

Finally, the Egyptian authoritarian emigration state would also promote a return policy aiming to have diaspora members contribute to the development of the homeland. The theme of citizens' return to the homeland, in particular, highlighted how labour emigration was approached not as an act of political treason, but as an economic necessity for Egypt's economic development. Mechanisms for the granting of dual citizenship to Egyptians were duly instituted. The Egyptian state put forth financial incentives (for instance, beneficial access to housing), or the ad hoc creation of 'Visiting Professor' posts in universities to be occupied by Egyptian scientists residing abroad (al-Ahram, 21 April 1974). Those who had emigrated illegally before 1970 (either as an act of political dissent or to escape the military draft) were free to return without persecution: Sadat decided to grant a 
general amnesty to all Egyptians who had escaped conscription and dispatched military delegations abroad inviting the emigrants back to Egypt. More prominently, the acts of emigration and, importantly, return migration were approached in a patriotic manner:

Egypt's youthful skills have stolen the limelight and come to be the country's staple crop. Some of them get higher salaries than Dr. Henry Kissinger while still in their forties. Some lead the same lavish life as Hollywood stars. They own villas with fragrant gardens and as many as three cars each. One of them travels by private helicopter from his country home to his place of work inside New York! But our country will not lose the brains we export to the outside world. For a successful Egyptian must be back home one day to drink again from the Nile and to live with the generous people [of Egypt]. An Egyptian travels but does not go for good, for he always returns (al-Akhbar, 30 June 1975).

\section{Turkish diaspora policies}

The Turkish state encouraged labour emigration from the late 1950s onwards, primarily to Germany and, to a lesser extent, other Western countries (Aksel, 2014; Sayari, 1986). While Germany has remained a main country of destination ever since (Figure 4), the Turkish state also promoted labour emigration to the Arab world and Russia in the post-1973 era, as demand for immigrant labour in Europe declined.

Similar to Egypt, authorities initially framed the state's exit policy around the potential economic and developmental contribution of migration to the Turkish state from the 1960s onwards (Martin 1991). According to the IIBK's 1964 report, labour migration would serve five aims, namely:

Realising the idea of integration of the country into the European political and economic community; reducing under-employment as much as possible; raising hard currency revenues; unskilled and semi-skilled worker's acquisition of knowledge, ability and experience; and, by increasing the number of people with European work-methods and experience within the country, encouraging industries of the receiving countries to set up subsidiaries in Turkey (quoted in Akgündüz, 2008, p. 52).

Already in 1950, Turkish law clarified that no exit visas are required to leave Turkey (Art. 7, Law No. 5682) and posed no residency requirements for those already employed within Turkey: a 1975 SOPEMI report found that $81 \%$ of Turkish emigrants were already employed prior to emigration. In fact, as per its 1961 agreement with the Federal Republic of Germany, a liaison office was established in Istanbul that formed a branch of the German Bundesanstalt für Arbeit, which coordinated the recruitment process and made the final selection of emigrants on behalf of the German state. Realizing the economic benefits of migrant remittances, the Turkish state engaged in a series of migration-related agreements with host states, as in 


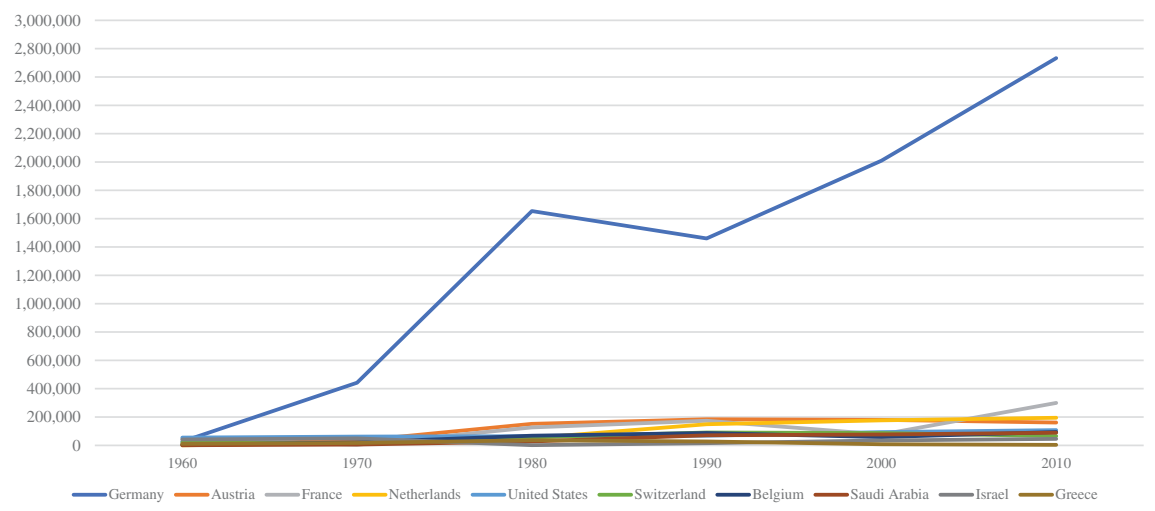

Figure 4. Turkish migrant stock in major countries of destination [1960-2010]. Source: World Bank (2011)

the case of Egypt. However, obstacles to emigration remained, particularly for Turkey's Kurdish citizens in the 1980s. When the 1973 oil-embargo diminished Western Europe's appetite for immigrant labour, Turkish authorities targeted Libya, Jordan, and the oil-producing countries of the Gulf. It is worth noting that, similar to Egypt, different ministries shared responsibility for these policies, including the Ministries of Labour, Finance, Education, Foreign Affairs, Customs and Local Affairs, the Turkish Employment Service, as well as the Turkish State Planning Organization.

With regard to its overseas policy, Turkey developed extensive outreach mechanisms for its diaspora populations, particularly within Europe (Baser 2017). These evolved out of the need to incentivize the dispatch of economic remittances into a broader set of policies that provided social assistance and facilitation of diasporic organizations abroad, in a manner reminiscent of Egypt. Dedicated institutions - such as the Office for Turks Abroad and Related Communities (YTB) - have been created with an economic, sociocultural, but also political rationale. Turkey aims to project 'soft power' abroad through these communities but also aiming to ensure the well-being of these communities, to have a greater say in EU states' politics. In Europe, Turkey has sought to secure host states' cooperation in monitoring and restricting dissidents' behaviour policing' (Østergaard-Nielsen, 2003, p. 94), similar to intra-Arab security cooperation in the Egyptian case. Turkey has also demonstrated behaviour similar to Syria and Libya with regard to its treatment of the Kurdistan Workers' Party (PKK) and PKK-related organizations and individuals abroad. Abdullah Öcalan, the PKK leader, was captured in Kenya and returned to Turkey, in February 1999; assassinations of Kurdish activists abroad have also been attributed to the MIT, or the Turkish Intelligence Service (Adamson 2018). 
At the same time, the state's return policy involved a number of provisions put in place for returnees: the Turkish state clarifies that no visa requirement is needed for Turkish citizens to return home (Art. 5, Law No. 5682) and Article 23 of the 1982 Constitution also states that no citizens may be deprived of the right to return to the homeland. However, Turkish consulates have been known to refuse the issuance or renewal of passports to political dissenters - primarily trade union activists - and force them to return to Turkey to resolve the issue in a process that Østergaard-Nielsen called 'passport harassment' $(2003,94)$. This is reminiscent of Syrian practices both in terms of the hostility created between the diasporic communities and state institutions abroad, as well as in the authoritarian emigration state's aim of forcing regime dissenters to return home. In 1981, Turkey legalized dual citizenship, while the Constitution established the Higher Coordination Council for Workers, including the Social Affairs and Economic Affairs Committees, aiming to strengthen the attachments of diaspora groups to Turkey (Aksel, 2014, pp. 203-204). At the same time, however, Turkey has engaged in denaturalization practices against individuals that acquired a second citizenship without informing consular authorities. As in Syria, cases of harassment by Turkish consulate officials against opposition groups, including the Kurds, the Alevites, and members of the Gülen movement, have been widely reported (Röhn, 2017).

\section{Jordan diaspora policies}

The Jordanian state has encouraged labour emigration from the late 1950s onwards, and its national economy depends to a large degree on migration and remittances (Shami, 1999, pp. 140-51; Brand, 2006, pp. 176-215). The majority of emigration flows occur towards the Arab oil-producing countries of the Gulf, notably high-skilled Jordanians and Palestinians - by the 1970s, around $60 \%$ of the Jordanian labour force was working in the Gulf (Thiollet, 2011 , p. 11). Such flows continue today, with the exception of a period of economic downturn and return migration from the mid-1980s to the early 2000s (Figure 5).

Similar to Egypt, the Jordanian authoritarian emigration state facilitated emigration through its exit policy. Until 1962, the Jordanian state implemented an exit visa policy that aimed at preventing the emigration of political activists, for any hint of suspicion about one's political affiliation would lead to rejection (Abu-Odeh, 1999, p. 83). However, from 1962 onwards the Jordanian rentier state relied on remittances and the steady outflow of emigrants, and adapted its policy accordingly: it ceased keeping detailed records of emigration flows and adopted an open-door policy, similar to that of Egypt. This included a number of bilateral agreements with host states, starting with a Jordanian-Kuwait accord in 1958, followed by agreements 


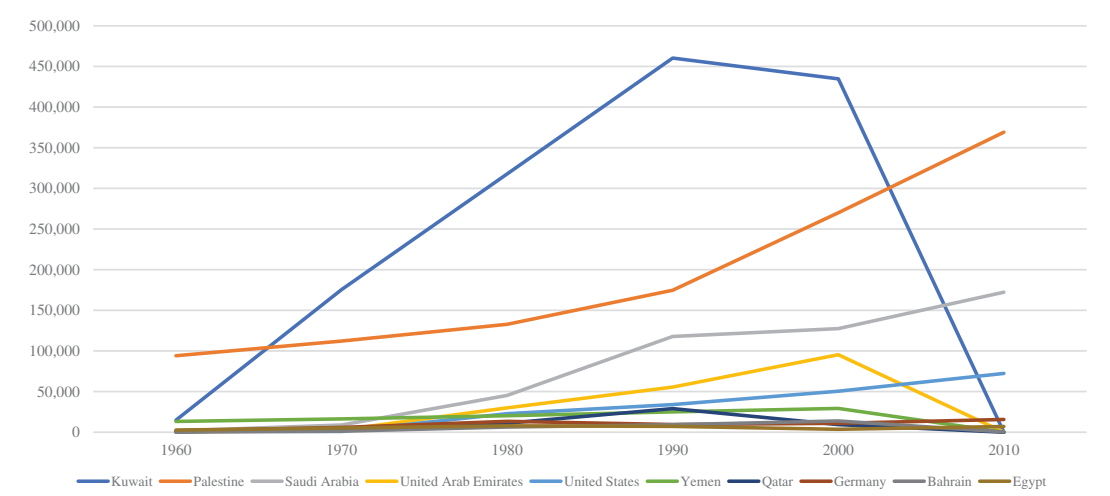

Figure 5. Jordanian migrant stock in major countries of destination [1960-2010]. Source: World Bank (2011)

with Pakistan and Libya in 1978. Together with Egypt and (pre-Assad) Syria, Jordan had also signed a 1967 agreement calling for the free circulation of labour workers in the Arab world. As in the case of Egypt, Jordan attempted to normalize the phenomenon of labour emigration through textbooks: the 2010 Jordanian tenth-grade civics textbook, for instance, highlights how countries such as Egypt and Jordan benefitted from migration to the Gulf and states that 'with the tremendous flow of oil in the Gulf region and in Libya, new waves of population and labor force movement began, employment opportunities expanded ... and the processes of migration and movement of labor to the oil regions became one of the more important forces shaping contemporary Arab life' (Brand, 2010, p. 105). In contrast to Syrian and Turkish attempts at keeping political discontents within their borders, Jordan did not forcibly detain them at home. Similar to Egypt, Jordan relied on close security cooperation with the Gulf states to monitor and suppress political activism (Brand, 2013).

Indeed, similarities exist in Egyptian and Jordanian overseas policies. The Ministry of Foreign Affairs had established a special section on expatriate affairs in 1981. The 1981-85 Five-Year Plan laid out specific strategies for the dispatch of labour attachés at the main countries of destination, such as Kuwait and the United Arab Emirates, to resolve any problems and support expatriates' activities. In 1987, Jordan decided to establish an Expatriates Directorate (mudiriyyat al-mughtaribin) in the Ministry of Labour and Social Development. The Jordanian state also initiated a series of expatriate conferences, which would annually invite hundreds of Jordanians residing abroad back to the homeland to share their opinions on how to further develop linkages with the diaspora. The existence of large expatriate communities across the Middle East was 
framed, as in the case of Egypt, in pan-Arab terms and was presented as contributing to regional economic integration and Arab unity. At the same time, once ruling elites perceived of the Palestinian population (and the Palestine Liberation Organization) as a threat to a Jordanian national identity, Palestinian migrants' activities abroad came under close scrutiny. As in the case of Syrian and Turkish communities abroad, Palestinian Jordanians developed a culture of reticence, even fear, towards state institutions abroad:

'for many expatriates, the relationship to Jordan was one of an imposed nationality, while political loyalty belonged to one of the factions of the PLO. One might well own an apartment or a home in Jordan, but this was because to do so in Palestine was much more difficult or impossible. Jordanian embassies were places where passports had to be renewed, but which were otherwise to be avoided. The state was increasingly associated with a Transjordanian-staffed internal intelligence service that impounded passports, harassed, and at times tortured suspected political activists' (Brand, 2006, pp. 181-82).

Finally, in terms of Jordanian policy of return: by 1987, the Jordanian Parliament responded to expatriate requests and approved dual citizenship (Jordan Times, 18 July 1987). Those who participated in the Expatriate Conferences were taken on tours of development projects across Jordan and made familiar with state initiatives that would allow them to pursue economic activities back in the homeland. They were offered special hotel rates (according to instructions by the Ministry of Tourism and Antiquities) and flight tickets on Royal Jordanian Airlines (cf. Jordan Times, 14 July 1986). Yet, as with other Middle East authoritarian emigration states, Jordan also uses its return policy for political ends - particularly with regard to Palestinian Jordanians that hold 2- or 5-year passports (Human Rights Watch, 2010). This precarity adds another level of control over migrant groups. Beyond the issue that these documents do not constitute full citizenship, they have allowed state officials to arbitrarily strip Jordanians of their nationality - in effect, making them stateless for a second time after 1948.

\section{Conclusion}

This article attempted to fill a gap in the existing literature on states' diaspora policymaking by identifying how non-democracies, in particular, develop multi-tier diaspora engagement policies that target different groups of citizens at various stages in their mobility. By arguing that authoritarian emigration states have the capacity to generate, shape, as well as dismantle diasporas, I demonstrate how diaspora engagement policies need to be broken down into exit, overseas, and return policies, respectively. Across the five Middle Eastern cases examined, all states (Libya, Syria, Egypt, 
Turkey, and Jordan) developed complex policies that targeted citizens differently at different times. Going beyond unitary conceptualizations of diaspora policymaking as solely targeting population groups abroad, the article has highlighted the diverse policy tools at the disposal of states and aimed to contribute to the on-going research in state-diaspora relations, Middle East studies, and the politics of authoritarianism.

A cursory examination suggests that a number of Middle Eastern states develop similar, multi-tier diaspora policies: Algeria, Tunisia, and Morocco, for instance, developed permissive exit and return policies that encouraged labour emigration to Western Europe in the past, similar to the policies developed by Egypt, Turkey, and Jordan. All three states also developed overseas policies that involved intense surveillance of their diaspora groups abroad. As discussed in the Introduction to this article, Egypt has adopted numerous in the aftermath of the 2011 Arab Uprisings, including the expansion of 'black lists' and closer monitoring of diaspora communities in Europe, which resemble Libyan and Syrian policies. Similar practices are currently evident in Turkey.

Further work is necessary to understand policy variation, across both time and cases. Why do Libya and Syria appear to develop more repressive diaspora policies than Egypt, Turkey, or Jordan? How does regime change affect diaspora policymaking across authoritarian emigration states? It appears that domestic shifts towards harsher authoritarianism are reflected on a state's approach to diaspora policymaking. At the same time, additional work is needed to understand interaction across policy tiers - it appears that authoritarian emigration states with permissive exit policy are more concerned about controlling populations abroad via their overseas policy, as in Algeria, Tunisia, and Morocco; however, states that restrict exit appear less likely to expand resources on expansive overseas or return policies, as in pre-Gaddafi Libya or Egypt under Nasser. The rationale behind authoritarian emigration states' multi-tier diaspora policies continues to be an unexplored dimension of the state-diaspora relations literature.

\section{Notes}

1. Seminal earlier accounts include Østergaard-Nielsen's work on Turkey (2003) and Brand's work on Arab states (2006).

2. Drawing on work by Hollifield and Gamlen (Gamlen, 2008; Hollifield, 2004), I define authoritarian emigration states as 'the set of institutions, practices, and mechanisms regulating cross-border mobility developed within non-democratic contexts' (for a full discussion, see: Tsourapas, 2018a).

3. Recent work challenging this includes Koinova (2018); Adamson (2018); Adamson and Tsourapas (2019).

4. Although word limitations in a comparative analysis of five case-studies prevent a full discussion of how these policies change over time, I have 
attempted to include as much detail on diaspora policies' evolution as possible.

5. This is encapsulated in Article 13b of the Universal Declaration of Human Rights, which states that 'everyone has the right to leave any country, including his own, and to return to his country'.

6. The annual event celebrated the exodus of the Italian and Jewish communities from post-independence Libya.

\section{Acknowledgement}

An earlier version of this article was presented at the 'Diasporas and Contested Sovereignty' conference at the University of Warwick, 28-29 September 2017. I would like to thank Maria Koinova, Catherine Ruth Craven, and the conference participants for valuable feedback. I would also like to thank Ahmad Barakat and Hannah Betyna for invaluable research assistance.

\section{Disclosure statement}

No potential conflict of interest was reported by the author.

\section{Funding}

This work was supported by the British Academy [Grant No. SG163246] and the Council for British Research in the Levant [2017 Pilot Study Grant].

\section{ORCID}

Gerasimos Tsourapas (D) http://orcid.org/0000-0002-2746-9752

\section{References}

Abu-Odeh, A. (1999). Jordanians, Palestinians \& the Hashemite Kingdom in the Middle East Peace Process. Washington, DC: United States Institute of Peace.

Adamson, F. (2018). Sending states and the making of intra-diasporic politics: Turkey and its diaspora(s). International Migration Review. Forthcoming.

Adamson, F., \& Tsourapas, G. (2019). Migration diplomacy in world politics. International Studies Perspectives, 20(2).

Akgündüz, A. (2008). Labour migration from Turkey to Western Europe, 1960-1974: A multidisciplinary analysis. Hampshire, UK: Ashgate Publishing, Ltd.

Aksel, D. B. (2014). Kins, distant workers, diasporas: Constructing Turkey's transnational members abroad. Turkish Studies, 15(2), 195-219.

Alemán, J., \& Woods, D. (2014). No way out: Travel restrictions and authoritarian regimes. Migration and Development, 3(2), 285-305.

Al-Jazeera. 2017. Vietnam exiles dissident after revoking his citizenship. Retrieved 2017, June 26 from http://www.aljazeera.com/news/2017/06/vietnam-exiles-dissi dent-revoking-citizenship-170625150005282.html. 
Amin, G. A., \& Awni, E. T. (1986). Hijrat Al=amālah Al-Misrịyah: Dirāsah Naqdīyah Lil-Buhụth Wa-Al-Dirāsāt Al-Khāsșạh Bi-Hijrat Al-amālah Al-Mișīyah Ilá Al-Khārij [Egyptian Labor Migration: A Critical Study of Research and Studies on the Migration of Egyptian Workers Abroad]. Ottawa: Markaz al-Buhụth lil-Tanmiyah al-Dawlīyah.

Amnesty International. 2011. The long reach of the Mukhabaraat: Violence and harassment against Syrians abroad and their relatives back home. Retrieved from http://www.refworld.org/docid/4e8e94e52.html.

Associated Press. 2018. Rights group: Syria's new property law discourages return. Associated Press, May 29, 2018, https://apnews.com/5a45e2c36ba84e0abda12cb14d278783.

Awad, l., \& Selim, H. (2017). Labour migration governance in times of political transition: A comparative analyisis of Egypt and Tunisia. Migration and Development, 6(1), 1-13.

Baser, B. (2017). Emigration and diaspora policies in the age of mobility. 221-238. Cham: Springer.

Betts, A., \& Jones, W. (2016). Mobilising the diaspora - how refugees challenge authoritarianism. Cambridge: Cambridge University Press.

Black, I. 2011. Gaddafi's Libyan rule exposed in lost picture archive. The Guardian, July 18, 2011, sec. World news. http://www.theguardian.com/world/2011/jul/18/gad dafi-brutal-regime-exposed-lost-archive.

Brand, L. A. (2002). States and their expatriates: Explaining the development of Tunisian and Moroccan emigration-related institutions. San Diego: University of California.

Brand, L. A. (2006). Citizens abroad: Emigration and the state in the Middle East and North Africa. Cambridge: Cambridge University Press.

Brand, L. A. (2010). National narratives and migration: Discursive strategies of inclusion and exclusion in Jordan and Lebanon. International Migration Review, 44(1), 78-110.

Brand, L. A. (2013). Jordan's inter-Arab relations: The political economy of alliancemaking. New York: Columbia University Press.

Bredeloup, S., \& Pliez, O. (2011). The Libyan migration corridor. Florence: European University Institute.

Brinkerhoff, J. M. (2005). Digital diasporas and governance in semi-authoritarian states: The case of the Egyptian Copts. Public Administration and Development, 25(3), 193-204.

Carman, T. 2015. Two generations of Syrian refugees find sanctuary in Vancouver. http://www.vancouversun.com/life/generations+syrian+refugees+find+sanctuary +vancouver/11622736/story.html

Chalcraft, J. (2008). The invisible cage: Syrian migrant workers in Lebanon. Stanford: Stanford University Press.

Collyer, M. (ed). (2013). Emigration nations: Policies and ideologies of emigrant engagement. New York: Palgrave Macmillan.

Dalmasso, E. (2018). Participation without representation: Moroccans abroad at a time of unstable authoritarian rule. Globalizations, 15(2), 198-214.

Délano Alonso, A., \& Mylonas, H. (2017). The microfoundations of diaspora politics: Unpacking the state and disaggregating the diaspora. Journal of Ethnic and Migration Studies, 1-19.

Dessouki, A. E. H. (1982). The shift in Egypt's migration policy: 1952-1978. Middle Eastern Studies, 18(1), 53-68.

Escriba-Folch, A., Meseguer, C., \& Wright, J. 2018 Remittances and Protest in Dictatorships, American Journal of Political Science, https://doi.org/10.1111/ajps.12382. 
Fahim, K. 2011. Rebel insider concedes weaknesses in Libya. The New York Times, March 23, 2011, https://www.nytimes.com/2011/03/24/world/africa/24minister.html.

Feiler, G. (2003). Economic relations between Egypt and the Gulf Oil States, 1967-2000: Petro-Wealth and patterns of influence. Brighton: Sussex Academic Press.

Fergany, N. (1983). Al-Hijrah Ilá Al-Naft: Ab'ād Al-Hijrah Lil-'amal Fì Al-Buldān AlNaftịyah Wa-Atharuhā 'alá Al-Tanmiyah Fì Al-Watạn Al-'arabī [Migration to Oil: Dimensions of Labour Migration in Oil Countries, and Its Impact on Development in the Arab World]. Beirut: Markaz Dirāsāt al-Wahḍah al-'Arabīyah.

Fitzgerald, D. (2009). A nation of emigrants: How Mexico manages its migration. Berkeley: University of California Press.

Gamlen, A. (2008). The emigration state and the modern geopolitical imagination. Political Geography, 27(8), 840-856.

Gamlen, A. (2014). Diaspora institutions and diaspora governance. International Migration Review, 48(September), S180-S217.(Forthcoming)

Glasius, M. (2017). Extraterritorial authoritarian practices: A framework. Globalizations, 15(2), 179-197.

Greenhill, K. M. (2010). Weapons of mass migration - Forced displacement, coercion, and foreign policy. Ithaca: Cornell University Press.

Han, E. (2017). Bifurcated homeland and diaspora politics in China and Taiwan Towards the overseas Chinese in Southeast Asia. Journal of Ethnic and Migration Studies, doi:10.1080/1369183X.2017.1409172.

Harvey, C., \& Barnidge, R. P. (2005). The right to leave one's own country under international law. Belfast: Global Commission on International Migration.

Hirschman, A. O. (1993). Exit, voice, and the fate of the German democratic republic: An essay in conceptual history. World Politics, 45(2), 173-202.

Hirt, N., \& Mohammad, A. S. (2017). By way of patriotism, coercion, or instrumentalization: How the Eritrean Regime makes use of the diaspora to stabilize its rule. Globalizations, 15(2), 232-247.

Hollifield, J. F. (2004). The emerging migration state. International Migration Review, 38(3), 885-912.

Human Rights Watch. (1999). World report 2000. New York: Human Rights Watch.

Human Rights Watch. 2010. Jordan: Stop withdrawing nationality from Palestinian-origin citizens. Human Rights Watch. February 1, 2010. https://www.hrw.org/news/2010/02/ 01/jordan-stop-withdrawing-nationality-palestinian-origin-citizens.

Kawczynski, D. (2011). Seeking Gaddafi: Libya, the West and the Arab Spring. London: Biteback Publishing.

Koinova, M. (2018). Sending states and diaspora positionality in international relations. International Political Sociology, 12(2), 190-210.

Koinova, M., \& Tsourapas, G. (2018). How do countries of origin engage migrants and diasporas? Multiple actors and comparative perspectives. International Political Science Review, 39(3), 311-321.

Koven, R. 1980. Prominent enemy of Syria's Assad is slain in Paris. Washington Post, July 22, 1980. https://www.washingtonpost.com/archive/politics/1980/07/22/prominentenemy-of-syrias-assad-is-slain-in-paris/03d0ff98-33a5-4c84-9fe8-a3b0b3df0851/.

Lafleur, J.-M. (2013). Transnational politics and the state: The external voting rights of diasporas. New York: Routledge.

Libyan Arab Jamahiriya. 1979. Libyan nationality law. https://www.multiplecitizen ship.com/wscl/ws_LIBYA.html. 
Maghur, A. 2010. Highly-skilled migration (Libya) - Legal aspects. CARIM Analytic and Synthetic Notes. Florence: European University Institute. http://cadmus.eui.eu/bit stream/handle/1814/13685/CARIM_ASN_2010_31.pdf?sequence=1\&isAllowed=y.

Martin, P. L. (1991). The unfinished story: turkish labour migration to western europe with special reference to the federal republic of germany. Geneva, Switzerland: International Labour Office.

Michaelson, R. 2016. Arrest of leading Egyptian feminist Azza Soliman sparks anger. The Guardian, December 7, 2016, http://www.theguardian.com/world/2016/dec/ 07/womens-rights-activist-azza-soliman-arrested-in-egypt.

Mirilovic, N. (2014). Regime type, international migration, and the politics of dual citizenship toleration. International Political Science Review, 36(5), 510-525.

Mirilovic, N. (2016). Regime type and diaspora politics: A dyadic approach. Foreign Policy Analysis. 14(3), 346-366.

Moss, D. M. (2016). Transnational repression, diaspora mobilization, and the case of the Arab spring. Social Problems, 63(4), 480-498.

Moss, D. M. (2018). The ties that bind: Internet communication technologies, networked authoritarianism, and 'voice' in the Syrian diaspora. Globalizations, 15(2), 265-282.

Natter, K. (2015). Revolution and political transition in Tunisia: A migration game changer?. Washington, DC: Migration Policy Institute.

Naujoks, D. (2013). Migration, citizenship, and development: Diasporic membership policies and overseas Indians in the United States. New Delhi: Oxford University Press.

Obeidi, A. (1999). Political culture in Libya. Richmond: Curzon.

Østergaard-Nielsen, E. (2003). Turkey and the 'Euro Turks': Overseas nationals as an ambiguous asset. In E. Østergaard-Nielsen (Ed.), International migration and sending countries: Perceptions, policies and transnational relations (pp. 77-98). Houndmills: Palgrave Macmillan.

Paoletti, E. (2010). The migration of power and north-south inequalities: The case of Italy and Libya. Basingstoke: Palgrave Macmillan.

Paoletti, E. (2011). Migration and foreign policy: The case of Libya. The Journal of North African Studies, 16(2), 215-231.

Pargeter, A. (2012). Libya: The rise and fall of Qaddafi. New Haven: Yale University Press.

Parolin, G. P. (2009). Citizenship in the Arab world: Kin, religion and Nation-State. Amsterdam: Amsterdam University Press.

Philipp, T. (1985). The Syrians in Egypt: 1725-1975 (Vol. 3). London: Coronet Books Incorporated.

Reuters. 1981. Wife of Syrian dissident is Slain in West Germany. The New York Times, March 18, 1981. https://www.nytimes.com/1981/03/18/world/around-the-worldwife-of-syrian-dissident-is-slain-in-west-germany.html.

Rodriguez, R. M. (2010). Migrants for Export: How the Philippine state brokers labor to the world. Minneapolis: University of Minnesota Press.

Röhn, T. 2017. Erdogan-Gegner Erleben Im Türkischen Konsulat Böse Überraschung. Die Welt. March 19, 2017. https://www.welt.de/politik/deutschland/arti cle162961336/Erdogan-Gegner-erleben-im-tuerkischen-Konsulat-boeseUeberraschung.html.

Ross, J. 1982. Qaddafi threatens dissidents overseas. Washington Post, December 6, 1982. https://www.washingtonpost.com/archive/politics/1982/12/06/qaddafithreatens-dissidents-overseas/d7bfa1d3-22b5-419a-a8df-a39805e9ed26/. 
Sayari, S. (1986). Migration policies of sending countries: Perspectives on the Turkish experience. The Annals of the American Academy of Political and Social Science, 485, 87-97.

Shain, Y. (2005). The frontier of loyalty: Political exiles in the age of the nation-state. Ann Arbor: University of Michigan Press.

Shami, S. (1999). Emigration dynamics in Jordan, Palestine and Lebanon. In R. Appleyard (Ed.),Emigration Dynamics in Developing Countries, 4, 128-201. Aldershot: Ashgate

The Economist 2016. To silence dissidents, Gulf states are revoking their citizenship. The Economist, November 26, 2016. http://www.economist.com/news/middle-eastand-africa/21710679-many-are-left-stateless-result-silence-dissidents-gulf-states-are.

The Independent. 2016. Turkey coup: Erdogan bans all academics from leaving country as government crackdown intensifies. July 20, 2016. https://www.indepen dent.co.uk/news/world/europe/turkey-coup-erdogan-academics-ban-leaving-coun try-government-crackdown-latest-a7146591.html.

Thiollet, H. (2011). Migration as diplomacy: Labor migrants, refugees, and Arab regional politics in the oil-rich countries. International Labor and Working-Class History, 79(1), 103-121.

Tsourapas, G. 2015a. The politics of Egyptian migration to Libya. Middle East Research and Information Project. http://www.merip.org/mero/mero031715.

Tsourapas, G. (2015b). Why do states develop multi-tier emigrant policies? Evidence from Egypt. Journal of Ethnic and Migration Studies, 41(13), 2192-2214.

Tsourapas, G. (2016). Nasser's educators and agitators across Al-Watan Al-'Arabi: Tracing the foreign policy importance of Egyptian regional migration, 1952-1967. British Journal of Middle Eastern Studies, 43(3), 324-341.

Tsourapas, G. (2017). Migration diplomacy in the Global South: Cooperation, coercion \& issue-linkage in Gaddafi's Libya. Third World Quarterly, 38(10), 2367-2385.

Tsourapas, G. (2018a). Authoritarian emigration states: Soft power and cross-border mobility in the Middle East. International Political Science Review, 39(3), 400-416.

Tsourapas, G. (2018b). The peculiar practices of 'authoritarian emigration states'. British Academy Review, 32, 22-24.

United States Department of State. 2012. Country Report on Human Rights Practices, 2011, Libya. https://www.state.gov/j/drl/rls/hrrpt/humanrightsreport/index. htm\#wrapper.

Vandewalle, D. (2012). A history of modern Libya (2nd ed.). Cambridge: Cambridge University Press.

Winckler, O. (1997). Syrian migration to the Arab oil-producing countries. Middle Eastern Studies, 33(1), 107-118.

Zohry, A., \& Harrell-Bond, B. (2003). Contemporary Egyptian migration: An overview of voluntary and forced migration. Sussex: Development Research Centre on Migration, Globalisation and Poverty. 